\title{
ANTIBACTERIAL ACTIVITY OF PLUMERIA OBTUSA (LINN)
}

\author{
Renu Singh \\ Department of Pharmacy \\ Indore Institute of Pharmacy, Indore, M.P, India
}

\begin{abstract}
Herbal medicines have great importance in treatment of diseases since ancient times. Plumeria Obtusa which is a herbal medicinal plant and is used for gastroprotective activity, Anti-mutagenic activity, Antibacterial activity and anti-inflammatory activity due to the presence of iridoid like 6"-O-acetylplumieride p-Ecoumarate and 6"-0-acetylplumieride -p-Z-coumarate. Iridoids are basically secondary metabolites present in various plants, especially in species belonging to the Apocynaceae, Lamiaceae, Rubiaceae, Scrophulariaceae and Verbenaceae families. The paper's aim is to summarize the antibacterial activity and that has been demonstrated. Plumeria Obtusa is an important source of many pharmacologically and medicinally important chemicals such as plumeride, isoplumeride, fluvoplumericin, irriod glycoside and other various minor secondary metabolites. The study of antibacterial activity with different extracts obtained from different parts of the plant, which show that the compounds have beneficial effects against a number of diseases. As the scenario is now changing through out the world towards the use of non toxic plant products, development of modern drugs from Plumeria Obtusa should be emphasized. This research on Plumeria Obtusa focuses over antibacterial activity with a scope of development in future.
\end{abstract}

Keywords-Antibacterial ativity, iridoids, Plumeria Obtusa

\section{INTRODUCTION}

Ayurveda, the ancient Indian therapeutic measure is renowned as one of the major systems of alternative and complementary medicine. As other ayurvedic medicine, greater parts of its medicaments are based on native herbals and the thorough knowledge about the medicinal plant is must for everyone is working in the field of Ayurveda for identifying and selecting the appropriate plant for a specific disease. In last few years, the interest in medicinal plants has increased in a great extent. Apart from this people from the western countries have also taken this issue so seriously by conducting various researches on plant based medicines.

Plumeria obtusa, commonly called as white frangipani, is a small, rounded tree of the dogbane family that typically grows to $10-15^{\prime}$ tall but less frequently to $25^{\prime}$ tall. It is main origin is the Bahamas and the Greater Antilles, but has been introduced

\author{
Dilip Kumar Verma \\ Department of Quality Assurance \\ Mylan Lab, Indore, M.P, India
}

into a number of tropical areas around the world. Plumeria obtusa is a species of Plumeria, native to Greater Antilles, northern Central America \& southern Mexico. It is a large shrub trees or small tree growing to a height of 8 metres (26 $\mathrm{ft}$.). It is also found in West Bengal, Kolkata \& various other places in India. It is grown for decorating purpose in gardens. 5-Petals with white flowers (to $13 / 4$ " diameter) with nice fragrance Flowers bloom in clusters from spring till their fall, with heaviest bloom often occurring in month of July and August. In Hawaii, the flowers are commonly used to make perfumes $^{[1]}$

Various types of plumeria obtuse found various parts of world.

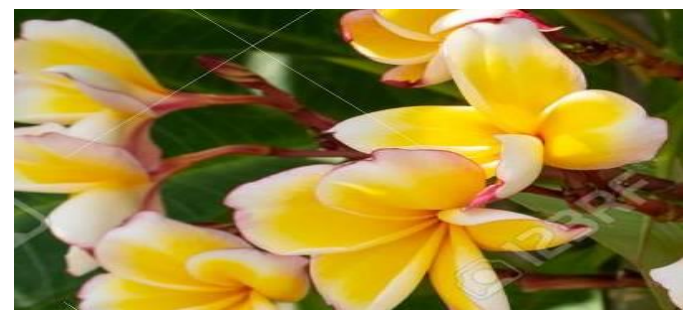

Fig 1. P. obtusa found in Singapore

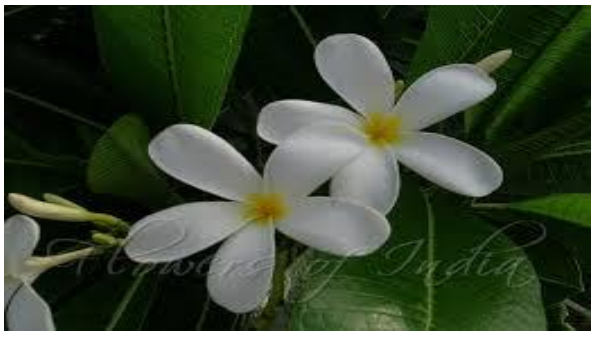

Fig 2. P. obtusa found in Greater Antilles

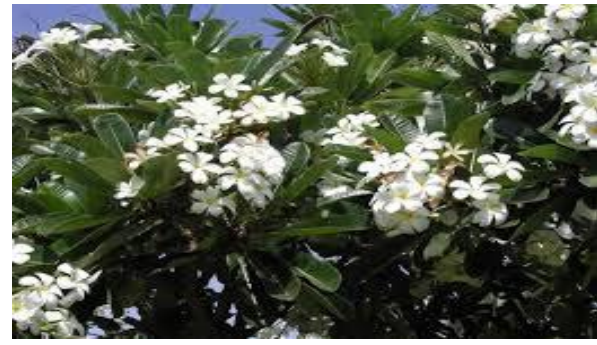

Fig 2. P. obtusa found in Brisbane, Australia 


\section{International Journal of Engineering Applied Sciences and Technology, 2019 \\ Vol. 4, Issue 8, ISSN No. 2455-2143, Pages 300-305 \\ Published Online December 2019 in IJEAST (http://www.ijeast.com)}

Traditional Uses;

In India, frangipani is a symbol of immortality because of its ability to produce leaves \& flowers even after it has been lifted out of soil.

In Vietnam, frangipani is used for its healing qualities, the bark; mashed in alcohol, prevents skin inflammation.

Also used to treat indigestion \&high blood pressure.

Roots have purgative effect on animals.

Milk like sap, though poisonous, serves as a balm for skin diseases.

White flowers are used in traditional medicine to cure high blood pressure, cough, haemophilia, dysentery \& fever hyper proliferative tissue with gastroprotective activity, Anti-mutagenic activity, Anti-bacterial activity and antiinflammatory activity due to the presence of iridoid. ${ }^{[17]}$.

The oil of P. obtusa was found to be rich in benzyl salicylate (45.4\%) and benzyl benzoate $(17.2 \%)$, but also minute concentrations of alkanoic acids. ${ }^{[11]}$

A decoction of leaves of Plumeria obtusa is used for treating wounds and skin diseases. latex and bark of Plumeria obtusa posses purgative and diuretic properties. ${ }^{[12]}$ Also The stem bark of Plumeria obtusa shows antiulcer effect.

In the Sekhukhune District of South Africa, decoction of leaves is taken three times daily for diabetes ${ }^{[13]}$ In Asia, the decoction of leaves is used for treating wounds and skin diseases. Bark and latex are used as diuretic and purgative $\mathrm{e}^{[14]}$

Chemical constituents P.obtusa contain pentacyclic triterpenoids namely kaneroside, oleandrin, $\alpha$-amyrin, neriucoumaric acid, isoneriucoumaric acid, alphitolic acid, oleanonic acid, methyl p-E-coumarate and scopoletin. ${ }^{[2]} 6$ "'Oacetylplumieride. ${ }^{[3]},{ }^{[4]}$ PlumieridePcoumarate. ${ }^{[5]}$, Obtusilinin ,Oleandrin, Obtusol. ${ }^{[6]}$ Obstusin ,Obstusilic acid, $\beta$-Hydroxy27-[(Z)-p- coumaroyloxy]-urs-12-en-28- oic acid, Obtusinin, Obtusilin (1/4 3b-hydroxy-11-oxours- 12-en-28oic acid), Obtusinidin, Obtusidin, 27-[p-(E)-Coumaroyloxy] ursolic acid (20Z)-Dammara-,20(22)-dien(3 $\quad \beta, 20 Z)$ dammara-12,20(22)-dien-3-ol, (3ß)-Olean-12-ene-3, 27diol, 27-Hydroxyolean-12-en-3,Urs-12-en-3-one, (3 $\beta)$-27[(Z)-Feruloyloxy]-3- hydroxyurs-12-en-28-oic acid. ${ }^{[7]}$. Uvaol (1/4(3b)-3,28-dihydroxyurs-12-ene). ${ }^{[7]}$ iridoids 6"'-Oacetylplumieride p-E-coumarate.$^{[9]}$
Structure of some of the important chemical constituents.

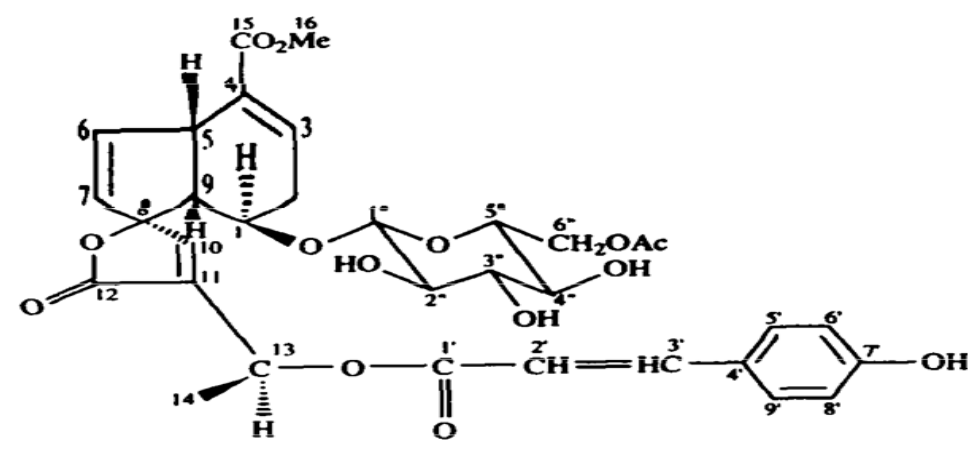

2',3'E(6"-O-acetylplumieride p-E-coumarate)

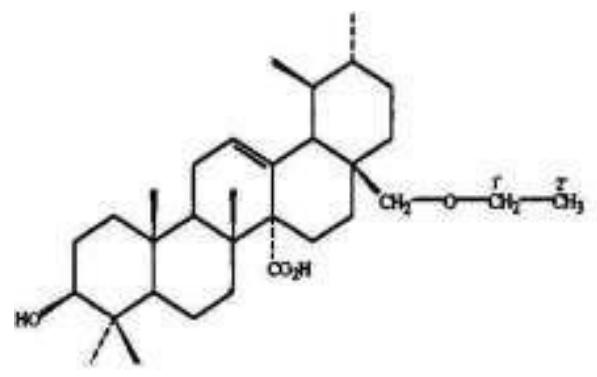

obtusilinic acid<smiles>O=C(OCc1ccccc1)c1ccccc1O</smiles>

Benzyl Salicylate<smiles>O=C(OCc1ccccc1)c1ccccc1</smiles>

Benzyl Benzoate 


\section{EXPERIMENTAL WORK}

Material and Methods:

\subsection{Collection Of Plants}

The leaves of Plumeria obtusa were collected from I.I.S.T. campus and surrounding areas during February 2019.

A proper herbarium sheet containing stem, leaf, flower was prepared and plant was given authentication by Dr.K.C.BHATT, NBPGR, PUSA.

They were cleaned (washed) with water to remove solid particles, dust material and other debris. Then they were dried under sunlight for few days.

The dried leaves were then grounded to a coarse powder in a grinder and stored in a well closed air -tight container.

\subsection{Selection Of Solvent}

Solvent used- Methanol, Chloroform, Distilled water, Benzene, Petroleum ether, Acetic acid, Acetone.

\section{Preliminary screening}

Tests for alkaloids, glycosides, flavonoids, saponin glycosides, tannins were done and based on that,

methanol was selected as solvent as maximum constituents were found to be present in it.

\subsection{Plant Extract}

The Soxhlet apparatus was washed and dried properly.

$37 \mathrm{gm}$. of the coarse dried powder was fitted in the soxhlet apparatus in a thimble and subjected to extraction by methanol.

The extraction was stopped after completion of 12 to 15 cycles in 24 hours.

The solvent was then evaporated by heating the extract obtained, in water bath.

A semi-solid, dark, viscous extract of the crude drugs so obtained was vacuum dried and then used for antibacterial studies.

Wt. of the extract was found to be $4.23 \mathrm{gm}$.

Further dilutions were made by dissolving required amount of extract in DMSO (di methyl sulphoxide).

\subsection{Bacteria Used For The Determination Of Antibacterial} Activity of Plant Extract

The bacterial strains used for the present investigations were clinical isolates obtained from Department of Pharmaceutical Technology, Jadavpur university and Institute of Microbial Technology (IMT), Chandigarh.

The bacterial strains used are:

\begin{tabular}{|l|l|}
\hline Name of the Strain & No Of Strain \\
\hline Pseudomonas aeruginosa & AP585NLF \\
\hline Pseudomonas aeruginosa & MTCC424 \\
\hline Actinobacter species & AP586 \\
\hline Morganelle morganii & AP590 \\
\hline Salmonella typhi & MTCC733 \\
\hline Proteus vulgaris & AP679NLF \\
\hline Staphylococcus aureus & ML267 \\
\hline
\end{tabular}

\begin{tabular}{|l|l|}
\hline Staphylococcus aureus & MTCC3750 \\
\hline Vibrio cholerae & 1023 \\
\hline Shigella boydii & 22461 \\
\hline Shigella sonoi & E08869 \\
\hline Shigella flexneri type & $36 N K 381$ \\
\hline Shigella somnei & E08869 \\
\hline Klebsiella pneumonia & MTCC109 \\
\hline Enterobacter species & AP596 \\
\hline Escherichia coli & ETEC LT57 \\
\hline
\end{tabular}

\subsection{Standard Antibacterial Agent Used For Comparison Of Antibacterial Activity}

Amoxycillin reference standard was used as a standard antibacterial agent.

\subsection{Media}

\section{Nutrient Agar Medium IP 1996}

\subsection{Dilution Techniques For Antibacterial Activity \\ 2.7.1 Preparation of Plates}

Nutrient Agar medium of the given composition was prepared $(300 \mathrm{ml}) .30 \mathrm{ml}$ of the media was dispensed in one 50 $\mathrm{ml}$ conical flask and $29 \mathrm{ml}$ of the media was dispensed in a number of $50 \mathrm{ml}$ conical flask, plugged with cotton and sterilized in autoclave at $121^{\circ} \mathrm{C}, 15$ psig for 30 minutes. Stock solution of $10 \mathrm{mg} / \mathrm{ml}$ was prepared. The $70 \mathrm{~mm}$ petridishes were sterilized in autoclave at the same temperature as above. Measured quantities of the stock solution were poured in molten nutrient agar medium to prepare concentrations of 50 , 100,200 , and $400 \mu \mathrm{g} / \mathrm{ml}$ of the extract and then poured aseptically in the sterilized petridishes in front of HEPA filter. The petridishes were marked accordingly. One sterile nutrient agar medium petriplate without the extract served as control.

These plates were refridgerated at $4^{\circ} \mathrm{C}$ for overnight for uniform diffusion of the Plumeria obtusa leaf extract throughout the media. The plates were dried at $25^{\circ} \mathrm{C}$ by keeping them in the incubator at this temperature for about 2 hour prior to spot inoculation and location for each test organism was marked at the back of the agar containing petridishes.

\subsubsection{Preparation of inoculum}

One loopful (loop diameter: $3 \mathrm{~mm}$ ) of an overnight grown nutrient agar medium culture of each test organism served as the inoculum for such antibacterial activity determination.

\subsubsection{Minimum Inhibitory Concentration (MIC)}

The petridishes containing the medium were marked in a checker board design. Each marked area in the Nutrient Agar Medium plates was inoculated by a sterile nichrome wire loop with one loopful of the prepared inoculum containing the specific bacterial test organism ie; $\mathrm{S}$ aureus, P.aeruginosa and S.typhi. Thus each plate was inoculated with all the test organism on the allotted positions and after inoculation all the plates were incubated at $25^{\circ} \mathrm{C}$ for $24 \mathrm{hrs}$.

No growth of the organism on the test plate along with the growth on the control plate was taken as an indicator of 
antibacterial activity of the drug. The readings were recorded in a tabular form.

The minimum inhibitory concentration or MIC was indicated by the least concentration of the extract at which no growth was observed.

2.8 Disc Diffusion Method For The Determination Of Antibacterial Potency Of The Extract And Its Comparison With A Standard Antibacterial Agent

The stock solution (each of $10 \mathrm{mg} / \mathrm{ml}$ ) of both extract and Amoxycillin were prepared. From these stock solutions two sets of five dilutions i.e. reference and extract (10, 20, 30, 40, $50 \mu \mathrm{g} / \mathrm{ml}$ ) each of leaf extract (solvent -DMSO) and Amoxycillin (solvent- distilled water) were prepared. Sterile agar medium plates were prepared and incubated at $25^{\circ} \mathrm{C}$ for $24 \mathrm{hrs}$. to check the presence of any sort of contamination.

Then each sterilized agar plates were flooded with liquid culture of bacterial strains and then dried for 30 minutes at $25^{\circ} \mathrm{C}$ after drawing the excess bacterial suspension. The sterile What man filter paper disc (4 mm diameter) were soaked in five different dilutions of the crude extract and placed in appropriate position of the plates marked as quadrant at the back of petridishes.

All the flooded plates with the corresponding paper discs soaked with appropriate dilution of the extract were incubated in incubator at $25^{\circ} \mathrm{C}$ for $24 \mathrm{hrs}$. Diameter of zone of inhibition were measured in $\mathrm{mm}$ and the similar procedure was adopted for Amoxycillin and corresponding zone diameters were measured and compared accordingly.

\section{RESULT}

Table No. 3: Anti Bacterial Activity of Various Extract of powdered leaves of Plumeria obtusa. (L.) using S.typhi, S.aureus and P.aeruginosa as test microbe

\begin{tabular}{|c|c|c|c|c|c|}
\hline $\begin{array}{c}\text { Test } \\
\text { micro } \\
\text { be }\end{array}$ & \multicolumn{5}{|c|}{ Zone of inhibition(mm) } \\
\hline Std & $\begin{array}{c}\text { Chlorof } \\
\text { orm } \\
\text { extract }\end{array}$ & $\begin{array}{c}\text { Methanol } \\
\text { extract }\end{array}$ & $\begin{array}{l}\text { Aceto } \\
\text { ne } \\
\text { extrac } \\
\text { trac }\end{array}$ & $\begin{array}{c}\text { Aqueous } \\
\text { extract }\end{array}$ \\
\hline $\begin{array}{c}\text { S.aure } \\
\text { us }\end{array}$ & 32 & 14 & 17 & 10 & 16 \\
\hline $\begin{array}{c}\text { S.typh } \\
\text { i }\end{array}$ & 33 & 15 & 19 & 10 & 14 \\
\hline $\begin{array}{c}\text { P.aeru } \\
\text { ginosa }\end{array}$ & 31 & 14 & 18 & 14 & 14 \\
\hline
\end{tabular}

Graphical Representation of Antibacterial Activity of Various Extract of Powder Leaves of Plumeria obtusa (L.) [Standard: Ciprofloxacin 1mg/ml and Dose of Test Extract: 1mg/ml]

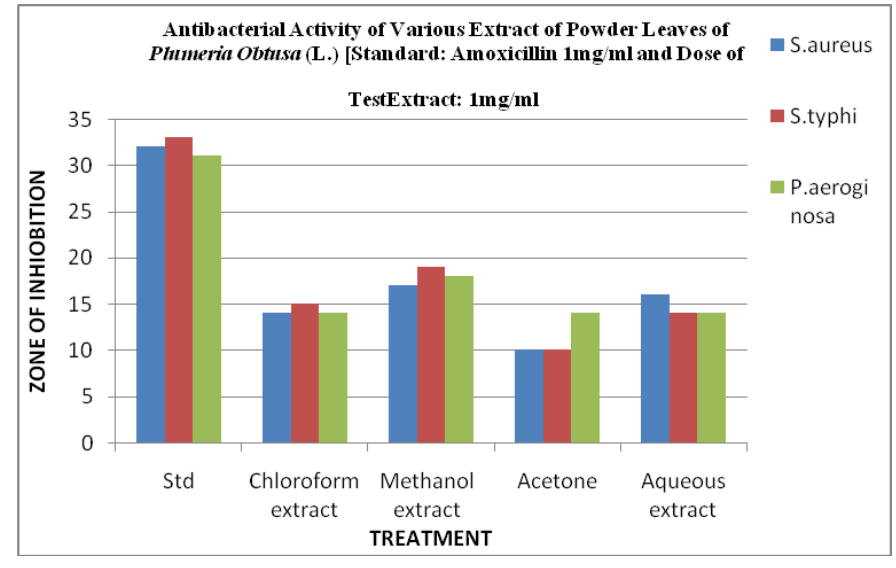

Amoxicillin

(a) Sterile Disc of Whatmann filter paper no. 1 of $6 \mathrm{~mm}$ diameter was prepared.

(b) Nutrient Agar media were prepared, sterilized and poured on to sterile Petri dishes and then kept in the incubator at $37^{\circ} \mathrm{C}$ for $24 \mathrm{hrs}$.

(c) One set of two dilutions each of extract and amoxacillin was prepared and stored in a properly capped volumetric flask.

(d) All plates were filled with their corresponding culture of the test organism under Laminar Airflow in aseptic room and left for 30 minutes

(e) The excess inoculum was discarded using a sterile Pasteur pipette

(f) Sterile disc were soaked in these dilutions and placed on the corresponding quadrants of the flooded nutrient Agar plates marked at the back with same concentration. This was done both for the test compounds as well as amoxicillin

(g) The plates were kept overnight in the incubator at $37{ }^{0} \mathrm{C}$. After incubation, the diameter of zone of inhibition around each disc was measured and the results were tabulated for various compounds and amoxicillin. . ${ }^{[15],[16]}$ 
Table-2:Determination of minimum inhibitory concentration (MIC) of the various leaves extracts of Plumeria obtuse $\mathbf{L}$

\begin{tabular}{|c|c|c|c|c|c|c|}
\hline \multirow[t]{2}{*}{ S.No. } & \multirow[t]{2}{*}{$\begin{array}{l}\text { Test } \\
\text { Compoun } \\
\text { ds. }\end{array}$} & \multirow[t]{2}{*}{$\begin{array}{r}\text { Name of the } \\
\text { Bacteria }\end{array}$} & \multicolumn{4}{|c|}{$\begin{array}{l}\text { Growth media } \\
\text { containing different } \\
\text { concentration of the } \\
\text { extract in } \mu \mathrm{g} / \mathrm{ml}\end{array}$} \\
\hline & & & \begin{tabular}{l|}
$\mathbf{5 0}$ \\
$\mu \mathrm{g} /$ \\
$\mathrm{ml}$ \\
\end{tabular} & $\begin{array}{l}100 \\
\mu g / \\
\mathrm{ml}\end{array}$ & $\begin{array}{l}200 \\
\mu g / \\
\mathrm{ml}\end{array}$ & $\begin{array}{l}4000 \\
\mu g / m \\
1\end{array}$ \\
\hline \multirow[b]{2}{*}{ A } & \multirow{2}{*}{$\begin{array}{l}\text { Methanoli } \\
\text { c Extract }\end{array}$} & S.typhi & + & + & \pm & -- \\
\hline & & $\begin{array}{c}\text { P.aurigunos } \\
\text { a . }\end{array}$ & + & + & \pm & \pm \\
\hline & & S.aureus & + & + & + & + \\
\hline \multirow[b]{2}{*}{ B } & \multirow{2}{*}{$\begin{array}{l}\text { Chlorofor } \\
\mathrm{m} \\
\text { Extract }\end{array}$} & S.typhi . & + & + & + & \pm \\
\hline & & $\begin{array}{c}\text { P.aureginos } \\
\mathrm{a} .\end{array}$ & + & + & + & \pm \\
\hline & & S.aureus & - & - & + & + \\
\hline \multirow{3}{*}{$\mathrm{C}$} & Acetone & S.typhi . & + & + & \pm & -- \\
\hline & Extract & $\begin{array}{l}\text { P.aureginos } \\
\text { a . }\end{array}$ & + & + & \pm & -- \\
\hline & & S.aureus & - & - & - & + \\
\hline \multirow{3}{*}{ D } & \multirow{3}{*}{$\begin{array}{l}\text { Aqueous } \\
\text { Extract }\end{array}$} & S.typhi.. & + & + & + & \pm \\
\hline & & $\begin{array}{l}\text { P.aureginos } \\
\text { a . }\end{array}$ & + & + & + & \pm \\
\hline & & S.aureus & + & + & + &.+ \\
\hline
\end{tabular}

Fig. 1: Antibacterial activity of methanol, chloroform and acetone extracts of powdered leaves of Plumeria obtusa L.[Std.: Standard (Amoxicillin), C: Control,] S.aureus as test microbe

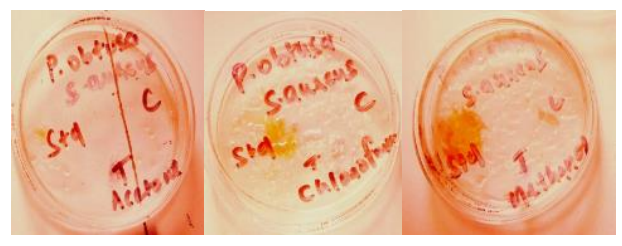

Fig. 2: Antibacterial activity of methanol, chloroform and acetone extracts of powdered leaves of Plumeria obtusa L.[Std.: Standard (Amoxicillin), C: Control,] S.typhi as test microbe

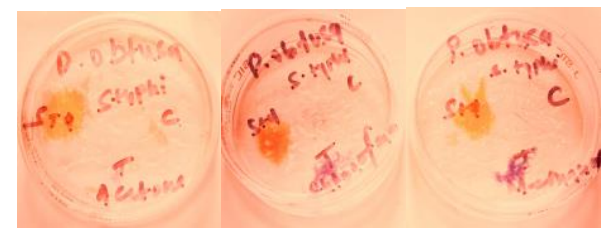

Fig. 3: Antibacterial activity of methanol, chloroform and acetone extracts of powdered leaves of Plumeria obtusa
L.[Std.: Standard (Amoxicillin), C: Control,] P.aeruginosa as test microbe

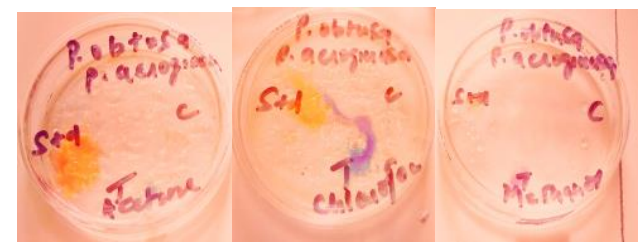

\section{DISCUSSION}

The results indicate that all the test extracts shows good inhibitory activity against all these bacterial strains. Chloroform extract and Acetone extract of leaves is showing partial antibacterial activity against S.aureus,P.aeruginosa and S.typhi where as complete good antibacterial activity is shown by Methanol extract and Aqueous extract in all the three test microbes ie; S.aureus,P.aeruginosa and S.typhi at $50 \mu \mathrm{g} / \mathrm{ml}$ $, 100 \mu \mathrm{g} / \mathrm{ml}, 200 \mu \mathrm{g} / \mathrm{ml}, 400 \mu \mathrm{g} / \mathrm{ml}$. Standard Ciprofloxacin is showing complete antibacterial activity against S.aureus and S.typhi and P.aerugunosa .

\section{CONCLUSION}

The literature survey revealed that this species of Plumeria is an important source of many pharmacologically and medicinally important chemicals such as plumeride, isoplumeride, fluvoplumericin, irriod glycoside and other various minor secondary metabolites. Study of antibacterial activity with different extracts obtained from the plant which show that the compounds have beneficial effects against a number of bacterial diseases. As the present scenario is now changing towards the use of non toxic plant products, development of ayurvedic drugs from Plumeria obtusa should be emphasized. Clinical trials should be conducted to support its therapeutic use.

\section{ACKNOWLEDGEMENT}

We are indebted to the Principal of Indore Institute of Pharmacy Dr. Dinesh Mishra for inspiring and supporting us at each step during our research work.

\section{REFRENCES}

[1] Missouri Botanical Garden.4344 shaw blvd St.louis MO 63110. S.(2012)

[2] Chin H. F. and Enoch I. C.(2002)Malaysian Flowers in Color Tropical Press, Kuala Lampur,Malaysia,; 188;85

[3] Siddiqui Salimuzzaman,Siddiqui B.S,Naeed Akhtar, Begum S,(1994) Pak. J. Sci. Ind. Res. Vol 32, no 12 
[4] Siddiqui B.S,Naeed A,Begum S and Siddiqui Salimuzzaman,(1994)Minor Iridoids From The Leaves Of Plumeria Obtusa.Phytochemistry,37(3): 769

[5] J .Walker(1992), The Subtropical Garden;: 83.

[6] Siddiqui.S., Siddiqui B. S., Naeed A., Begum S., (1992).Pentacyclic triterpenoids from the leaves of Plumeria obtuse. Phytochemistry; 31:4279.

[7] Siddiqui B.S, Ilyas F, Rasheed M, Begum S.(2004) Chemical Constituents of Leaves ,Stem Bark of Plumeria obtuse Phytochemistry; 65(14) 2077-2084.

[8] Hassan E. M., Shahat A. A., Ibrahim N. A., Vlietinck A. J., Apers S., Pieters L.,(2008) A new monoterpene alkaloid and other constituents of Plumeria obtuse Planta Med. 74, 1749.

[9] Akhtar N.(1992) Isolation \& Structural Studies On The Constitunts Of Calotropis Procera, Plumeria And Amberoboa Ramos. Pak Res Repositary 45-127

[10] Tembare D.Kumar R,Mani S(2012) An review of phytochemical constituents and pharmacological activities of Plumeria species Vol-4 issue -1

[11] .Wiart C(2002) Medicinal Plants of Southeast Asia. Kuala Lumpur, Pearson Malaysia,

[12] 3.Burkill IH. I-Z. Vol. 2. London: Crown Agents for the Colonies; 1935,Dictionary of the Economic Products of the Malay Peninsula.

[13] Semenya S, Potgieter M, T shisikhawe, Soul M Shava S , Maroyi A (2012). Medicinal utilization of exotic plants by Bapedi traditional healers to treat human ailments in Limpopo province, South Africa, Journal of Ethnopharmcology,; 144: 646-65

[14] Wong S.K, Lim Y.Y,Rain N,Juliana A and Juliana F(2011) Antiproliferative and phytochemical analyses of leaf extracts of ten Apocynaceae species Pharmacognosy Res. Apr-Jun; 3(2): 100-106. / doi: 10.4103/0974-8490.81957.

[15] Anonymous, Indian pharmacopeia, Government of India, Ministry of Health and Family Welfare, Controller of publication, Delhi,947-949, A-53-54, A124, A70-A71, A89, A74, A76, A105, 1996.

[16] Sharma B.K.,(2002) Instrumental method of Chemical Analysis, $21^{\text {st }}$ edition , Goel Prakashan, Meerut, 96-112, 134-216, 39-133, .

[17] Singh Renu, Vinchurkar Kuldeep,Dhokhane Surekha,Mishra Dinesh,(2019) Pharmacognostical and phytochemical evaluation of Plumeria Obtusa leaves .Prj ,Vol -8 ; Issue -9; 